\title{
ANALISIS BIBLIOMETRIKA ISLAM: STUDI KASUS DOKUMENTASI PUBLIKASI ILMIAH DI UIN SYARIF HIDAYATULLAH JAKARTA
}

\author{
Oleh : Nuryudi
}

\begin{abstract}
The research on analysis bibliometrics aimed to find out the development of Islamic sciences by looking at the productivity of the publication published in scientific journals. The research discusses the productivity of Islamic publication at UIN Syarif Hidayatullah Jakarta in the last five years (2010 - 2014) based on e-journal bibliographic with 498 articles. The finding of the research is the field of Shariah and Law study is the most progressive and most productive in the last five years. The indicators, more than 235 researchers contribute to the scientific publications of the period with the accumulation of 293 articles with 4 titles published in electronic journal. Meanwhile the field of Islamic Theology showed 107 titles of articles from 87 authors recorded on the three major journal in the same period. Others is Multi-disciplinary field registered around 98 scientific articles from 75 scientists recorded on three journal titles related to the fields. In conclusion, Sharia-law is the prominent field of study in productivity and publicity of scientific Islamic publication in this period.
\end{abstract}

Keywords: scientific publication, islamic bibliometrics, scholarship productivity

Abstrak

Penelitian analisis bibliometriks ini dilakukan bertujuan untuk mengetahui perkembangan keilmuan bidang ke-Islaman dengan cara melihat produktivitas karya yang telah diterbitkan lewat journal ilmiah. Disini dipaparkan gambaran produktivitas penerbitan karya ilmiah pada tiga bidang keIslaman di lingkungan UIN Syarif Hidayatullah Jakarta dalam periode lima tahun terakhir (2010 2014) berdasarkan data dari bibliografi e-journal dengan 498 artikel. Bidang yang lain tidak dapat dianalisis karena inkonsistensi publikasi online dan keterbatasan data yg ditemukan. Hasilnya, bidang kajian Syari'ah dan Hukum merupakan bidang subjek dengan karya ilmiah yang paling progresif dan paling produktif dalam kurun waktu lima tahun terakhir. Indikatornya, lebih dari 235 peneliti tercatat berkontribusi dalam publikasi ilmiah pada periode tersebut dengan akumulasi 293 artikel yang tertera dalam arsip 4 judul journal elektronik. Sementara bidang Ushuluddin menunjukkan 107 judul artikel dari 87 penulis yang terekam dalam 3 journal utama dalam kurun waktu yang sama. Dan bidang Multi-disiplin mendaftarkan sekitar 98 artikel ilmiah dari 75 ilmuan yang datanya terekam pada tiga judul journal bidang terkait. Dengan demikian, Syariah-Hukum sebagai bidang yang paling unggul dalam produktifitas dan publisitas karya ilmiah ke-Islaman dalam kurun waktu tersebut.

Kata kunci: publikasi ilmiah, bibliometrika islam, produktivitas keilmuan

\section{A. PENDAHULUAN}

\section{Latar Belakang}

Pertumbuhan dan perkembangan berbagai karya ilmiah perlu diberikan kemudahan bagi berbagai pihak yang berkepentingan untuk memperoleh sumber informasi. Kebutuhan sumber informasi digunakan oleh mereka baik untuk keperluan penguasaan, pendalaman dan pengayaan keahlian pada bidang yang relevan maupun untuk menguatkan atau membandingkan berbagai konsep-konsep yang dimilikinya sebagai hasil dari penyelidikan dan 
penelitian yang dilakukan. Hasil penelitian dapat saling menguatkan atau juga bisa jadi membantahnya. Karena itu, akses terhadap setiap artikel ilmiah harus mudah dilakukan dan full-tekt dokumen harus dapat dengan mudah diperoleh. Maka dari itu, setiap upaya pengelolaan dokumen dalam berbagai ragam karya publikasi ilmiah khususnya journal ilmiah harus dibarengi dengan tersedianya perangkat petunjuk untuk memudahkan akses koleksi tersebut.

Kemudahan akses terhadap dokumen publikasi ilmiah dapat dibangun dengan menciptakan berbagai infrastruktur, seperti indeks, abstraks, katalog dst., baik bersifat tradisional-manual maupun berbasis sistem digital online. Upaya ini biasanya dilakukan dengan mengelola sedemikian rupa sistem bibliografi yang terkait dengan setiap dokumen tersebut. Dalam upaya ini biasanya setiap bibliografi terkait dengan setiap dokumen diindeks dan disusun dalam sebuah daftar khusus bibliografi atau diimput dalam sistem komputerisasi yang dapat diakses secara online. Sehingga, semakin banyak terbitan yang dipublikasikan akan semakin banyak entri bibliografi yang dihasilkan. Akibatnya, hal ini akan membutuhkan tenaga, waktu dan energi yang tidak sedikit untuk mengelolanya dengan baik. Jadi, semakin besar daftar bibliografi sebagai cermin besarnya terbitan ilmiah akan semakin kompleks pengelolaannya untuk kemudahan akses. Dan juga semakin kompleks untuk diketahui perkembangan dan pertumbuhan keilmuan sesuai dengan klasifikasi bidangnya. Demikian juga penerbitan publikasi ilmiah dalam kajian ke-Islaman yang tercermin dalam bentuk bibliografi sesuai dengan bidangbidang kajian yang ada dalam Islam.

Bibliografi Islam baik yang bersifat konvensional maupun yang kontemporer membutuhkan bukan saja kemudahan akses untuk dokumen-dokumen yang besangkutan tetapi juga gambaran pertumbuhan bidangbidang keilmuan tersebut. Sebagai bahan referensi ilmiah bibliografi Islam harus memberikan gambaran yang jelas dan kemudahan akses terhadap setiap penerbitan dan publikasi karya ilmiah yang dikehendaki setiap pemustaka/peneliti. Sehingga setiap upaya penelitan dan kegiatan akademis yang akan memanfaatkan bahan-bahan sumber informasi tersebut sebagai referensi ilmiah dan acuan sitasi karya penulisan dapat difasilitasi dengan mudah. Setiap aktifitas sitasi dan referensi tehadap sumber-sumber informasi ilmiah tersebut akan membantu para peneliti untuk mengidentifikasi setiap konsep acuan yang diperlukannya, dan selanjutnya membantu masyarakat akademisi untuk mengetahui arah perkembangan keilmuan yang menjadi bidang kajiaannya. Untuk kemudahan tersebut maka pruduktifitas penerbitan ilmiah harus dapat dipetakan dalam sebuah matrik statistik lewat satu cabang ilmu bibliometriks.

Bibliometrika dikenal sebagai bidang kajian yang dapat mengungkapkan besaran dan keunggulan suatu bidang ilmu tertentu bahkan suatu lembaga pendidikan tertentu lewat penerapan berbagai teori di dalamnya seperti analisis kepengarangan, analisis sitiran, webometrik (bibliometrik berbasis web), kerjasama kepengarangan, keusangan dokumen, faktor dampak, dsb. Disamping itu, dengan biblimetrika juga dapat diketahui bagaimana produktifitas dan sebaran atau distribusi publikasi ilmiah tersebut dalam bidang keilmuannya. Dari aktifitas penelitian semacam ini akan dapat dilihat perkembangan suatu ilmu dengan cara mengamati dan mencermati hubungan kedekatan antar dokumen yang relevan dalam berbagai bentuk, baik tercetek maupun elektronik. Salah satu subjek kajian bibliometrika dalam Ilmu Perpustakaan dan Informasi ini bisa ikut berperan dalam menyajikan peta perkembangan keilmuan tertentu, termasuk diantaranya untuk menyajikan potret dinamika aspek kajian ilmu-ilmu ke-Islaman kontemporer.

Sekarang ini banyak tokoh-tokoh pemikir muslim yang giat menggali dan menganalisis temuan-temuan di berbagai bidang keilmuan, seperti di bidang ekonomi syariah dan kaitannya dengan konsep-konsep ke-Islaman kontemporer. Paradigma ini perlu terus diamati dan disebarluaskan informasinya untuk kemajuan perkembanngan keilmuan dengan berbagai ragam sumber informasi yang up to date dan komprehensif. 
Selanjutnya dengan kegiatan penelitian ini dapat pula digambarkan rasio pertumbuhan publikasi ilmiah berbanding dengan kuantitas para pengampu (dosen, ilmuan dan peneliti) yang tergabung pada masing-masing bidang keilmuan tersebut. Dan akan terlihat pula seberapa besar sumbangannya dalam kajiankajian tersebut sebagai bagian kontribusi pertumbuhan dan perkembangan keilmuan ke-Islaman di indonesia. Hal ini dapat dilihat berdasarkan peran kelembagaan dari setiap institusi Pendidikan Tinggi Islam Indonesia (PTAI) yang salah satunya adalah UIN Syarif Hidayatullah Jakarta.

Matrik produktifitas dan sebaran dokumen publikasi ke-Islaman kontemporer akan menjadi salah satu indikator kontribusi pemikiran Islam terhadap umatnya, untuk menyelesaikan berbagai persoalan umat yang semakin kompleks dan kompetitif. Hal ini khususnya nyata bila produk karya ilmiah tersebut sebagian besar atau seluruhnya merupakan produk penelitian yang didasarkan pada pencarian solusi persoalan umat dewasa ini. Seiring dengan profil pertumbuhan tersebut maka subject-subject atau bidangbidang kajian yang memberikan kontribusi besar tentunya patut mendapatkan apresiasi dan telah mencerminkan pertumbuhan yang baik sesuai dengan keinginan dan kebutuhan masyarakat luas dimana Islam sebagai mayoritas penduduk di Indonesia. Data dan informasi terkait dalam penelitian tentang publikasi ilmiah ini memberikan tampilan deskripsi perkembangan pemikiran dan keilmuan Islam secara kongkrit dan akurat lewat ilustrasi produktifitas ilmuan pada bidang yang bersangkutan.

Pusat sumber informasi dan pusat dokumentasi publikasi ilmiah khususnya di Lingkungan UIN Syarif Hidayatullah Jakarta dapat menawarkan berbagai sumber informasi khusunya dalam kaitannya dengan data bibliografi artikel sebagai bagian kajian dalam ilmu perpustakaan dan informasi. Lokasi ini merupakan lokasi utama penyimpanan dan dokumentasi koleksi publikasi ilmiah ke-Islaman yang telah berkembang sejak lama seiring dengan pertumbuhan programprogram pendidikan yang dikelola oleh organisasi terkait. Dalam penelitian ini data bibliografi diperoleh dari sumber infomasi khususnya dalam format journal ilmiah, tidak termasuk majalah populer atau bentuk sumber informasi lain.

Sampai saat ini, sesungguhnya berkaitan dengan bidang kajian penelitian dengan tema bibliomertiks telah dilakukan oleh beberapa peneliti pada bidang ilmu tertentu atau dengan pendekatan salah satu sub cabang bibliometriks. Sementara ini, untuk kajian pada topik ilmu-ilmu ke-Islaman belum pernah dilakukan di Indonesia. Sehingga, hal ini merupakan topik kajian yang menarik unuk diselenggarakan.

\section{Permasalahan Penelitian}

Untuk membatasi ruang lingkup penelitian ini agar lebih jelas dan mudah diselenggarakan maka tema kajian ini difokuskan pada pengkajian bibliografi publikasi ilmiah ke-Islaman di lingkungan UIN Jakarta. Artinya, pembahasan tidak termasuk ragam bibliografi kajian keislaman yang diterbitkan di luar Institusi ini. Pembahasan tersebut juga dibatasi pada penyelidikan bahan pustaka journal ilmiah yang terdapat pada dokumentasi publikasi elektronik UIN Syarif Hidayatullah Jakarta. Sekurangnya terdapat tiga hal sebagai cakupan batas persoalan yang menjadi fokus penelitian ini yakni (1) Dari segi teori yang digunakan dalam penelitian ini dibatasi pada implementasi aspek produktifitas ilmiah dalam subject tertentu, (2) Peran kepengarangan terkait dengan pertumbuhan kajian ilmiah ke-Islaman; (3) identias journal dalam area/ zona tertentu lewat penilaian keterkaitannya dengan subject yang dikaji.

\section{a. Rumusan Masalah:}

1. Bagaimana produktivitas penerbitan karya ilmiah pada bidang-bidang keIslaman di lingkungan UIN Syarif Hidayatullah jakarta dalam 2010 - 2014?

2. Bagaimana peran pengarang dalam kontribusi ilmiah mereka pada bidangbidang keislaman?

3. Bagaimana identitas eksistensi journal dalam area subject kajian ilmiah keIslaman di indonesia? 
b. Tujuan Dan Manfaat

1. Untuk mememperoleh gambaran produktivitas penerbitan karya ilmiah pada bidang-bidang ke-Islaman di lingkungan UIN Syarif Hidayatullah dalam periode 2010 - 2014.

2. Untuk mengetahui peran pengarang dalam kontribusi imiah pada bidangbidang ke-Islaman.

3. Untuk mengetahui identitas dan eksistensi jurnal dalam area subject kajian ilmiah ke-Islaman.

\section{B. LANDASAN TEORI DAN KERANGKA KONSEPTUAL}

Secara konseptual telah banyak para ahli yang menjelaskan konsep bibliometrika ini dalam penerapannya pada berbagai aktivitas penelitian di bidang ilmu perpusakaan dan informasi. Secara ringkas Richard dalam bukunya mengutip Wallace (1989) yang menyatakan bahwa yang dimaksud bibliometika adalah: "the application of quantitative methods to study of information resources"; penerapan metode kuantitatif terhadap kajian literatur sumber informasi. Selanjutnya dia menjelaskan, "Such a field explores patterns in the production of knowledge as well as the patterns of its use. ... bibliometric studies can also provide a broader understanding of entire disciplines, revealing with authors are most productive within a discipline and which countries or language produce greater amounts of materials within a field." ${ }^{1}$ Bahwa kajian seperti itu akan melakukan eksplorasi pola-pola produktivitas [publikasi informasi] dan juga bagaimana pola-pola pemanfaatannya. Kajian bibliometrika juga dapat memberikan pemahaman yang lebih luas terhadap keseluruhan disiplin-didiplin ilmu, mengungkapkan nama-nama pengarang mana yang paling produktif dalam suatu disiplin ilmu serta negara mana atau bahasa apa yang memproduksi [karya ilmiah] lebih banyak dalam suatu bidang ilmu.

Konsep biblioetrika ini merupakan penerapan analisis kuantitatif terhadap kajian

1 Richard E. Rubin. Foundations of Library and Information science. London: Neal Schuman Publishers, inc, Hal 46. literatur yang dilengkapi dengan teori-teori dasar yang tiga diantaranya yaitu: hukum Lotka, hukum Bradford, dan hukum Zipt. Nama-nama teori ini sesuai dengan nama para pencetus yang telah pertama-tama menggunakannya untuk melakukan analisis bibliografi dari berbagai ragam literatur publikasi informasi. Hukum tersebut dijadikan sebagai patokan atau acuan analisis kuantitatif oleh para peneliti di bidang perpustakaan dan informasi. Secara sederhana acuan tersebut menyatakan bahwa hukum Lotka (1926) berfungsi untuk menghitung distribusi produktivitas publiksi ilmiah oleh berbagai pengarang, hukum Bradford berperan dalam mendeskripsikan dokumen (biasanya majalah) dalam subject disiplin ilmu tertentu dimana kajian dilakukan dengan menganalisis jumlah artikel yang terbit dalam sebuah jurnal pada periode tertentu; Dan hukum Zipf (1933) bertugas untuk memberikan peringkat kata dan frekuensi pengulangan yang terdapat dalam literatur makalah atau artikel. Pengulangan kata tersebut disusun menurut jumlah prekuensinya dan diranking dari yang paling sering ke yang paling jarang diulang.

Sebagai penjelasan implementasi teori bibliometriks - hukum Lotka (Lotka's law) tersebut Richard mengemukakan sebagi berikut:

"Lotka (1926) observed that with a body of literature, there are a few authors who contribute a large number of publications, a larger number of authors who contribute a smaller group of publications, and then many authors who contribute a few or only one publication. This relationship was expresse as $(1 / \mathrm{n} 2)$, where $\mathrm{n}$ is the number of contributions. Hense, the number of authors making three contributions at the field would be one-ninth (3 pangkat2) of the total number of authors. The number of authors making four contributions would be one-sixteenth (4 pangkat 2). The pattern quikly becomes obvious; far fewer authors will be contributing a large number of contributions. Unlike actual physical laws, Lotka's law is not a perfect description of how authors and publications are related within a discipline, but generally it is a good estimate." ${ }^{2}$

2 Richard E. Rubin. Foundations of Library and Information Science. London: Neal Schuman 
Dari teks ini dapat dipahami bahwa dalam literatur [bidang ilmu tertentu] terdapat sedikit pengarang yang memberikan kontribusi ilmiah dengan jumlah yang besar, terdapat banyak pengarang yang berkontribusi sedikit publikasi, dan kemudian banyak lagi pengarang yang berkontribusi sangat sedikit bahkan hanya satu terbitan. Hubungan ini dapat dinyatakan dengan rumus 'satu per $n$ pangkat 2 ' dimana $\mathrm{n}$ merupakan jumlah bilangan kontribusi tersebut. Jadi pengarang yang berkontribusi tiga artikel adalah se-persembilan dari keseluruhan jumlah penulis dibidangnya, dan yang berkontribusi empat artikel sejumlah se-per-enambelas dari total pengarang aktif pada bidang terkait.

Sedianya enam subjek utama (Dakwah, Syariah, Adab, Tarbiyah, Ushuludin, Dan Islamic Studies) dalam kajian Islam dalam penelitian ini dipetakan dengan teori bibliometriks, dimana produktivitas publikasi ilmiah relevan yang telah tersedia sepanjang tahun 2010 sampai dengan 2014 dikaji secara intensif. Tetapi kerena inkonsistensi publikasi online dan keterbataan data yang diperoleh pada periode tersebut, maka tidak semua subjek bisa dianalisis. Adapun secara grafis kerangka teori pada penelitian ini dapat disaksikan pada diagram berikut ini.

\section{DIAGRAM KONSEP PENELITIAN dan KERANGKA TEORI}

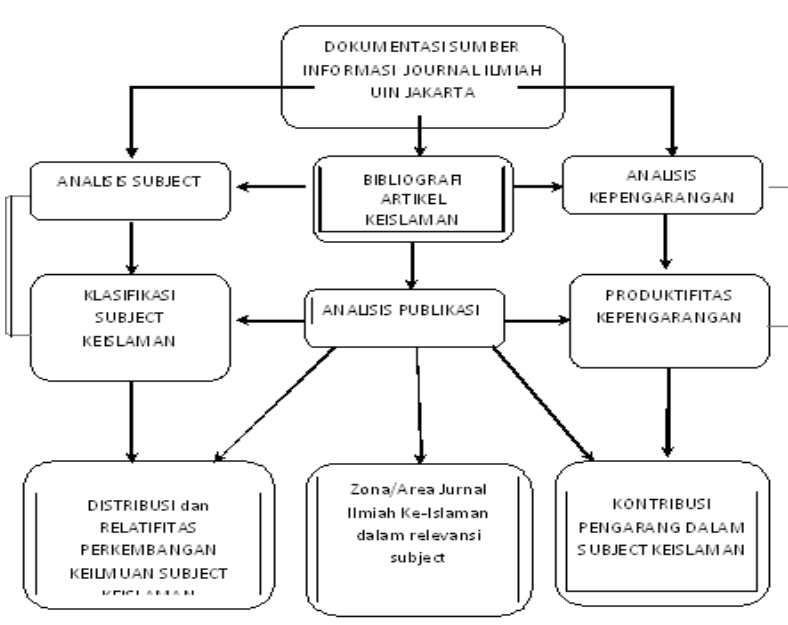

Publishers, inc, Hal 47.

\section{METODOLOGI}

\section{Deskriptif kuantitatif.}

Penelitian ini merupakan penelitian deskriptif dengan pendekatan kuantitatif. Dengan metode kuantitatif, dimaksudkan penelitian ini akan diarahkan untuk memperoleh data dan temuan secara deskriftif terhadap berbagai persoalan bibliometrika publikasi ke-Islaman di Indonesia. Tujuan utama penelitian ini adalah untuk memperoleh informasi deskriptif tentang persoalan publikasi ilmiah ke-Islaman sebagai bagian dari upaya pengamatan perkembangan keilmuan lewat penerbitan di Indonesia, khususnya koleksi publikasi ilmiah keIslaman. Dengan pendekatan ini diharapkan dapat diperoleh gambaran yang komprehensif dan akurat tentang peta publikasi ke-Islaman dan masalah-masalah terkait. Penelitian deskriptif ini akan memberikan gambaran yang detail tentang pola-pola kecenderungan perkembangan publikasi ilmiah pada bidang subject masing-masing, dan dijelaskan secara komprehensif peran kepengarangan dan keberadaan publikasi journal ilmiah pada subject yang bersangkutan.

Meskipun demikian, walaupun pada dasarnya penelitian ini menggunakana metode kuantitatif untuk pengumpulan data dan analisanya, tetapi untuk beberapa hal tidak semua dapat terselesaikan dengan metode tersebut maka dilakukan pendekatan kualitatif dengan purposive sampling dalam pengumpulan data bukan dengan cara random, sehingga hanya journal yang memiliki bibliografi elektronik secara lengkap dalam periode lima tahun terakhir yang ditetapkan sebagai sumber data analisis. Hal ini dilakukan untuk meningkatkan upaya menjamin objektivitas analisis data dimana bidang tertentu yang tidak ditemukan bibliografi journalnya secara kronologis dan sistematis dala cakupan periode waktu tertentu dapat mengurangi objektivitas analisis produktifitas pengagarang. Kelengkapan data dalam periode tersebut sangat menentukan bagaimana pola produktivitas ilmiah pengarang pada bidang yang bersangkutan. Sehingga terdapat beberapa bidang yang tidak dijadikan sampel, dan dalam penelitan ini sampel hanya diambil dari tiga bidang 
pokok, yakni Syari'ah - Hukum, Ushuluddin, Dan Multi Disiplin Islam (Islamic Studies).

\section{Subjek Penelitian}

Subjek utama dalam penelitian ini adalah pusat sumber informasi dan pusat dokumentasi publikasi ilmiah khususnya di Lingkungan UIN Syarif Hidayatullah Jakarta. Lokasi ini merupakan lokasi utama penyimpanan dan dokumentasi koleksi publikasi ilmiah ke-Islaman. Dalam penelitian ini journal sumber infomasi tersebut adalah khususnya format journal ilmiah yang terkonsentrasi pada dokumentasi publisitas e-journal atau open journal sistem (OJS) UIN, tidak termasuk majalah populer atau bentukbentuk sumber informasi yang lain.

\section{Sampel}

Populasi dari penelitian ini adalah berbagai ragam publikasi ilmiah yang berupa artikel ilmiah ke-Islaman yang tertera di berbagai jurnal dalam penerbitan online UIN. Journal yang menjadi sampel ditentukan secara purposife dan proporsional. Journal-journal yang terbit secara kronologis dan sistematis serta memberikan data elektroniks yang representatif dalam bidangnya menjadi bagian penting dalam kuantitas sampel. Besaran sampel penelitian diperoleh dengan asumsi bahwa total populasi bibliografi ke-Islaman sampai dengan tahun 2015 adalah sekitar 2000 artikel ilmiah. Sampel diperoleh dari perhitungan 10-20 \% dari populasi sehingga didapat sekitar 500 cantuman artikel yang dapat dianalisis.

\section{Kelemahan data indeks eletronik journal (OJS)}

Sistem OJS atau Open Journal Sistem yang dikelola UIN Syarif Hidayatullah Jakarta adalah sistem online yang tergolong baru, dimana proses uploading data bibliografi journal dalam publikasi lima tahun terakhir belum semua dilakukan. Artinya, journal yang memiliki dokumentasi file digital meskipun sudah lama masih mungkin menjadi bagian dari koleksi elektronik journal tersebut bila arsip journal yang bersangkutan dikelola dengan baik dan diintegrasikan. Sebaliknya bilajournalyang bersanguktan tidak meilikinya secara soft kopi maka dikhawatirkan tidak dapat mewakilkan artikel-artikelnya di upload secara online ke dalam database online tersebut. Hal ini terlihat untuk beberapa journal yang nampaknya dikelola dengan baik memiliki arsip file digital yang komrehensif, khusunya untuk periode lima tahun terakhir. Ketersediaan data pada database ini sangat membatu analisis penelitian ini bila data bibliogarafi yang terkait dengan journal dimaksud tersedia secara lengkap. Sistem OJS ini memungkinkan setiap journal untuk dapat diindeks dan memberikan akses terbuka setiap judul artikel yang dipublikasikan pada setiap nomor terbitnya. Namun demikian, masih banyak journal tidak memiliki data bibliografi yang lengkap dan sistematis. Tambahan pula terdapat journal-journal tergolong baru berdiri yang awal mula terbitnya seiring dengan masa pengembangan OJS tersebut dalam beberapa tahun terakhir. Jadi, meskipun judul-judul artikel dan kepengarangan dapat diketahui dengan mudah, tetapi database online tersebut belum mendaftar bibliogafi artikel-artikel dalam berbagai journal relevan secara utuh dan reprensentatif. Hal ini menjadi bagian kendala sumber acuan analisis perkembangan atau pertumbuhan karya ilmiah dalam bidangbidang yang bersangkutan. Sementara itu pusat dokumentasi yang lain, khususnya tercetak, tidak dapat diandalkan baik dari sisi organisasi koleksi maupun ketersediaannya. Dengan adanya kendala tersebut maka teori bradford yang berperan dalam mendeskripsikan dokumen sesuai subject disiplin ilmu, dimana kajian dilakukan dengan menganalisis jumlah artikel yang terbit dalam sebuah jurnal pada periode tertentu, tidak bisa dilaksanakan secara maksimal pada semua bidang yang dianalisis. Hal ini karena tidak semua judul journal yang telah teridentifikasi dapat diperoleh data bibliografinya baik dari arsip data tercetak maupun elektronik yang ada di pusat dokumentasi informasi dan perputakaan di lingkungan UIN Jakarta. Sehingga terbitan artikel dalam periode tertentu sulit teridentifikasi dengan pasti. 


\section{a) Analisa Relevansi Subjek}

Data yang telah terurai dan dipaparkan secara terstruktur memungkinkan untuk dapat dilakukan pengelompokan kategori subject. Pada tahap ini harus setiap entri kontent bibliografi artikel harus dapat teridentifikasi subject tertentu secara jelas. Redaksi entri subject dan sub-subject tertentu harus dapat diupayakan untuk mengelompok dan bersusun secara sistematis. Filing ini memungkinkan data dapat memberikan jumlah kuantifikasi setiap field yang diperlukan untuk memudahkan identifikasi subject bibliografi artikel tersebut. Sehingga, terlihat dengan mudah hubungan, keterkaitan dan perbedaan kategorinya kepada setiap subject yang telah ditetapkan. Pada tahap ini akan terlihat intensitas keterkaitan subject tersebut pada setiap journal ilmiah yang sedang dikaji baik journal-journal inti (core) maupun yang kemudian hanya sebagai penunjang subject disiplin tertentu. Aspek hubungan korelasi pada tahap ini dapat digambarkan dalam sebuah matriks yang korelatif sehingga peran masing-masing journal pada subjeknya dapat ditentukan.

Analisis yang kemudian dilakukan adalah terhadap beberapa Journal yang secara continue dan konsisten terindeks dalam database elektronik journal (OJS) UIN Jakarta, khususnya untuk bidang Syari'ah, Ushuludin dan Islamic Studies yang dapat memberikan data cukup komprehensif dan sistematis. Hukum Bradford dan Lotka yang berfungsi untuk mengamati perkembangan produktivitas dan publisitas ilmiah oleh berbagai pengarang di sini dapat dilakukan dengan baik terhadap sampel bibliorafi journal tersebut. Sedangkan untuk hukum zipf (1933) yang berfungsi sebagai alat analisis prekuensi kata dan relevansi subjek yang terdapat dalam literatur, dalam penelitian ini tidak terjangkau penerapannya. Sebagai gantinya digunakan analisis berdasarkan otoritas dan cakupan penerbitan.

\section{b) Identifikasi Produktivitas Penerbitan}

Pada tahap ini, tabulasi data yang telah dijabarkan secara deskriptif dan sistematis kemudian disarikan lagi menjadi sebuah matrik tabulasi korelatif pengarang dengan produktivias ilmiahnya. Gambaran secara kronologis penerbitan ilmiah dalam kurun waktu tertentu disajikan dengan lebih sederhana agar dapat diamati dengan mudah hasil karya setiap nama pengarang terkait. Deskripsi tersebut juga dapat menunjukkan fluktuasi penerbitan pada tahun-tahun tertentu dalam durasi yang telah ditetapkan dari tahun 2010 sampai 2014. Analisis produktifitas publikasi ini juga dapat menggambarkan aspek hubungan korelasi terkait dengan eksistensi subject tertentu. Dalam sebuah matriks tabel, setiap presentasi subject akan berkaitan atau mendapatkan nilai kuantitas frewensi penerbitan publikasi ilmiah yang relevan. Relatifitas frekuensi mulai dapat disaksikan dimana presentasi subject secara keseluruhan dapat mencerminkan kuantitas dan fluktuasi kontribusi artikel ilmiah yang berbeda-beda.

\section{c) Penyajian Data.}

Dengan metode kuantitatif ini diharapkan peneliti dapat memaparkan secara efisien serta dapat menginterpretasikan data temuan yang diperoleh yang telah dipresentasikan secara numerik. Sesuai dengan data yang tersedia, maka pada tahap ini dilakukn penjelasan secara sistematis seiring dengan sajian tabel data olahan yang telah disarikan dan ditampikan secara lebih sederhana dan akurat. Pada tahap ini landasan teori dan kerangka konseptual harus selalu diamati dan terus dicermati sehingga upaya interpretasi dan pembahasan tema-tema terkait tidak menyimpang dari kerangka teori dan konsep dasar yang telah dibangun. Analisa dan pembahasan data dapat menciptakan hubungan antara temuan-temuan baru, hasil penelitan sebelumnya dan konsep yang telah dibangun yang akan membentuk wacana yang positif dan memberikan informasi yang bermanfaat. Pada tahap pembahasan dan interpretasi ini juga dapat diperkuat dengan membandingkan atau mencocokan dengan pendapat para ahli pada bidang tersebut. Dengan demikian, penyajian data dan pembahasan permasalah- 
an dapat dipaparkan secara jelas dan objektif yang memungkinkan usaha menyusunan kesimpulan dapat dilakukan dengan mudah.

\section{HASIL PENELITIAN}

Pada bagian pertama analisa data berusaha untuk menyelesaikan persoalan bagaimana produktivitas penerbitan karya ilmiah pada bidang-bidang ke-Islaman di lingkungan UIN Syarif Hidayatullah Jakarta (2010 - 2014). Untuk mendapatkan kemudahan deskripsi dan analisis data berdasarkan bibliografi journal yang diperoleh dalam penerbitan dilingkungan UIN Jakarta, kemudian ditetapkan sebanyak 26 judul journal yang telah teridentifikasi. Jurnal tersebut kemudian diverifikasi dengan melengkapi informasi tentang tahun terbit dan kala terbitnya. Tahun pertama terbit dapat memberikan informasi bagaimana gambaran usia jurnal dan bagaimana produktifitasnya. Tidak semua jurnal memperoleh data tentang tahun pertama terbit karena tidak ditemukan informasi terkait dengan keterangan tersebut. Beberapa data tentang tahun terbit juga kadang meragukan untuk dicatat sebagai tahun waktu pertama terbit. Data tentang tahun pertama kali terbit ini sedapat mungkin diberikan secara akurat atau bila data tidak diperoleh maka diupayakan untuk memprediksi sedemikian rupa sehingga data waktu yang diberikan diperkirakan mendekati waktu pertama diterbitkan. Dari data tentang tahun terbit journal ilmiah tersebut diatas dapat diketahui bahwa terdapat berbagai macam usia journal keislaman dari yang tertua (1983) sampai yang termuda (2014).

D1. Bagaimana produktivitas penerbitan karya ilmiah pada bidang-bidang ke-Islaman di lingkungan UIN Syarif Hidayatullah Jakarta $(2010$ - 2014).

Journal yang dipandang telah berperan dalam peningkatan perkembangan kajian subjek yang bersangkutan ditetapkan sebagai sumber analisis data, terutama journal yang memiliki kontinuitas penerbitan lima tahun terakhir dengan bibliografi artikel yang lengkap. Maka dari itu, tidak semua journal dalam subjek tertentu dapat dianalis secara tuntas sesuai dengan pertumbuhan dan produktifitas ilmiah yang dihasilkan. Dari observasi penerbitan journal UIN, diperoleh informasi beragam judul journal tersebut terkait dengan enam sub-bidang ke-Islaman yang telah dipaparkan dalam tabel berikut:

\begin{tabular}{|c|c|c|}
\hline No & Bidang Kajian & Journal \\
\hline 1 & $\begin{array}{l}\text { Syari'ah, } \\
\text { Hukum \& } \\
\text { Ekonomi Islam }\end{array}$ & $\begin{array}{l}\text { a) Salam: Jurnal Sosial Dan } \\
\text { Budaya Syar' } \\
\text { b) Cita Hukum } \\
\text { c) Iqtishad } \\
\text { d) Ahkam: Jurnal IImu Syariah }\end{array}$ \\
\hline 2 & Ushuluddin & $\begin{array}{l}\text { a) Refleksi: jurnal kajian agama } \\
\text { dan filsafat } \\
\text { b) Sabda: Jurnal Studi IImu- } \\
\text { Ilmu Al-Qur'an dan Hadis } \\
\text { c) Journal of Qur'an and Hadith } \\
\text { Studies } \\
\text { d) Journal IImu Ushuluddin }\end{array}$ \\
\hline 3 & $\begin{array}{l}\text { Peradaban } \\
\text { Islam }\end{array}$ & $\begin{array}{l}\text { a) Kultur: The Indonesian Jour- } \\
\text { nal For Muslim Cultures. } \\
\text { b) Al-Turats: Mimbar Sejarah, } \\
\text { Sastra, Budaya Dan Agama, } \\
\text { c) Narasi: Media Penelitian } \\
\text { Agama Dan Budaya, } \\
\text { d) Manuskripta, }\end{array}$ \\
\hline 4 & $\begin{array}{l}\text { Multi-disiplin } \\
\text { Islam (Studi } \\
\text { Islam) }\end{array}$ & $\begin{array}{l}\text { a) Studia Islamika : Internation- } \\
\text { al Journal } \\
\text { b) Al-Zahra: Jurnal Studi Islam } \\
\text { Komprehensif } \\
\text { c) Indo-Islamika: Journal Of } \\
\text { Islamic Sciences } \\
\text { d) Jauharah: Jurnal Pemikiran } \\
\text { Islam Konstektual } \\
\text { e) Mimbar: Jurnal Agama dan } \\
\text { Budaya }\end{array}$ \\
\hline 5 & $\begin{array}{l}\text { Pendidikan } \\
\text { Islam. }\end{array}$ & $\begin{array}{l}\text { a) Tarbiya: Journal Of Educa- } \\
\text { tion In Muslim Society } \\
\text { b) Didaktika Islamika } \\
\text { c) Arabiyat: Jurnal Pendidikan } \\
\text { Bahasa Arab Dan Kebaha- } \\
\text { sa-Araban } \\
\text { d) Afaq Arabiyyah: Jurnal Pen- } \\
\text { didikan Bahasa Arab }\end{array}$ \\
\hline 6 & $\begin{array}{l}\text { Dakwah dan } \\
\text { Komunikasi } \\
\text { Islam }\end{array}$ & $\begin{array}{l}\text { a) Dakwah: Jurnal Kajian Dak- } \\
\text { wah Dan Komunikasi } \\
\text { b) Harkat: Jurnal Media Komu- } \\
\text { nikasi Jender } \\
\text { c) Journal Manajemen Dakwah }\end{array}$ \\
\hline
\end{tabular}

Penelitian ini bermaksud untuk melakukan komparasi semua sub-bidang subject keIslaman, tetapi bertujuan untuk memberikan gambaran pertumbuhan dan produktifitas karya ilmiah berdasarkan sumber data dan sumber bibliografi yang akumulatif. Data yang sistematis, komprehensif dan akumulatif 
dibutuhkan untuk mengetahui pertumbuhan dan produktifitas ilmiah pada bidang-bidang terkait secara objektif. Oleh karena itu, karena keterbatasan data yang terakumulasi disini data yang ada tidak dapat digunakan untuk melakukan komparasi pertumbuhan antar bidang ke-Islaman tersebut. Tetapi pada sumber data yang telah ditetapkan dan diperoleh sekitar 498 bibliografi artikel dalam kurun lima tahun terakhir dapat dijadikan bahan analisis dan dipandang cukup memadai sebagai representasi bahan kajian guna melihat pertumbuhan keilmuan dan produktifitas pengarang pada bidang terkait.

Enam bidang kajian ke-Islaman telah diupayakan dianalisis, karena keterbatasan waktu dan sumber data yang dapat diperoleh maka disini hanya dipaparkan tiga bidang dalam analisis produktifitas pengarang, yakni: Syari'ah-Hukum, Ushuluddin, dan MultiDisiplin (Studi Islam). Pada tiga bidang ini telah ditemukan journal-journal dengan data bibliografi yang dipandang representatif untuk analisis. Untuk itu diupayakan diperoleh data bibligrafi yang sistematis, komprehensif dan up to date. Journal-journal relevan diuraikan bagaimana gambaran produktifitas dan publisitas karya ilmiahnya dalam lima tahun terakhir. Dari hasil analisis data dapat diketahui bahwa bidang Syari'ah merupakan bidang kajian yang paling berkembang dan produktif dalam melahirkan artikel ilmiah dibandingkan dengan ke dua bidang lain tersebut berdasarkan sumber data yang terdapat pada OJS UIN Syarif Hidayatullah jakarta. Disini bidang Syari'ah - Hukum nampak paling progresif dalam melibatkan penulis berkontribusi dalam penulisan artikel ilmiah. Namun demikian hal ini tidak dapat dibandinkan dengan bidang lain di luar ketiga subjek tersebut karena belum dapat dilakukan akumulasi data yang bersangkutan secara tuntas dalam periode yang sama.

Dari paparan data yang diperoleh diketahui bahwa pada bidang Syari'ah dan Hukum telah terjadi perkembangan yang pesat dalam hal kontribusi pengarang terhadap pembinaan subjek terkait. Dari analisis bibliografi artikel ilmiah dalam empat journal selama periode 5 tahun terakhir sekurangnya tercatat 236 penulis atau peneliti yang berkontribusi dalam artikel ilmiah bidang Syari'ah Hukum. Sebanyak 294 judul artikel terkait berhasil diakumulasikan dari ketiga sumber tersebut, yang telah mendaftar nomor-nomor bibliografinya publikasi ilmiah. Pada sumber journal yang lain dalam bidang multi disiplin khususnya Indo-Islamika, dimana terdapat publikasi kajian syariah dengan jumlah yang cukup signifikan, yakni 7 artikel dalam tahun penerbitan 2012. Paparan ini menunjukkan perkembangan yang sangat produktif dalam pembinaan dan pengayaan bidang ilmu Syari'ah.

D.2. Bagaimana Peran Pengarang dalam Kontribusi Ilmiah pada bidang-bidang Ke-Islaman.

Tabel Analisis Produktifitas Pengarang Bidang Syari'ah-Hukum (2010-2014) dari Empat Journal

\begin{tabular}{|l|c|c|c|c|c|}
\hline \multirow{2}{*}{ Produktifitas } & \multicolumn{4}{|c|}{ Prekwensi Penerbitan } & \multirow{2}{*}{ Total } \\
\cline { 2 - 5 } & 1 & 2 & 3 & 4 & \\
\hline $\begin{array}{l}\text { Jumlah } \\
\text { pengarang }\end{array}$ & 188 & 39 & 9 & 0 & 236 \\
\hline Duplikasi & 0 & 39 & 18 & 0 & \\
\hline Total artikel & 188 & 78 & 27 & 0 & 293 \\
\hline Prosentase & 79,66 & 16,53 & 3,81 & 0 & 100,00 \\
\hline
\end{tabular}

Diperoleh sekitar 236 orang penyumbang artikel pada subjek SyariahHukum dalam periode lima tahun terakhir. Sebanyak 188 penulis atau sebesar 79,66 \% adalah mereka yang hanya berkontribusi satu kali dalam periode lima tahun terakhir. Sebesar 16,53 $\%$ atau sebanyak 39 orang berkontribusi dua kali penerbitan pada kurun waktu tersebut, seperti terlihat pada tabel di atas. Sedangkan yang telah berkontribusi tiga kali publikasi artikel ilmiah bidang syari'ah hukum adalah sebesar 3,81 atau sebanyak 9 orang pengarang, yakni : Andi Iswandi, Arip Purkon, Asmawi, Djawahir Hejazziey, Khamami Zada, M. Atho Mudzhar, M. Nur Rianto Al Arif, Nurul Huda, Rizqon 
Halal Syah Aji. Jumlah mereka sangat sedikit dibandingkan dengan para penulis kelompok kebanyakan dengan satu kali dalam kurun waktu empat sampai lima tahun.

Tabel Analisis Produktifitas Pengarang Bidang Ushuludin (2010-2014) dari Tiga Journal

\begin{tabular}{|l|c|c|c|c|c|}
\hline \multirow{2}{*}{ Produktifitas } & \multicolumn{4}{|c|}{ Prekwensi Penerbitan } & \multirow{2}{*}{ Total } \\
\cline { 2 - 5 } & 1 & 2 & 3 & 4 & \\
\hline $\begin{array}{l}\text { Jumlah } \\
\text { pengarang }\end{array}$ & 72 & 11 & 3 & 1 & 87 \\
\hline Duplikasi & 0 & 11 & 6 & 3 & $/$ \\
\hline Total & 72 & 22 & 9 & 4 & 107 \\
\hline Prekuensi & 82,76 & 12,64 & 3,45 & 1,15 & 100,00 \\
\hline
\end{tabular}

Sedangkan untuk bidang Ushuluddin, dari analisis bibliografi artikel ilmiah dalam tiga journal tersebut selama periode lima tahun terakhir sekurangnya tercatat 87 penulis atau peneliti yang berkontribusi dalam publikasi ilmiah bidang tersebut; Dan diperoleh sekitar 107 judul artikel yang berhasil diakumulasikan dari ketiga sumber journal. Partisipasi ini menunjukkan produktifitas pengarang yang aktif stabil pada pembinaan dan pengayaan bidang ilmu terkait.

Dari gambaran peran penulis terlihat bahwa budaya penulisan di bidang ini juga begitu dinamis, dimana teridentifikasi satu orang penulis yang tergolong sangat aktif dalam periode tersebut. Dia behasil mempublikasikan empat kali artikel ilmiah, yaitu Izza Rohman. Sedangkan pada periode tersebut yang telah berhasil tiga kali berkontribusi artikel ilmiah adalah sebesar 3,45 atau hanya sebanyak 3 orang penulis. Meraka adalah Jajang $A$ Rohmana, Kusmana, dan Eva Nugraha. Selanjutnya terdapat sebesar $12,64 \%$ atau sebanyak 11 orang mampu berkontribusi dua kali penerbitan artikel ilmiah dalam periode tersebut, nama-nama mereka adalah, Agus Darmaji, Andi Rahman, Ary Budianto, Budhy Munawar Rachman, Fuad Mahbub Siraj, Lilik Ummi Kaltsum, Media Zainul Bahri, Mohammad Anwar Syarifuddin, Mudhofir Abdullah, Nanang
Tahqiq, Rifqi Muhammad Fatkhi. Sebanyak 72 penulis atau sebesar $82,76 \%$ adalah mereka yang hanya berkontribusi satu kali dalam periode tersebut.

Tabel Analisis Produktifitas Pengarang Bidang Studi Islam (2011-2015) dari Tiga Journal

\begin{tabular}{|l|c|c|c|c|c|}
\hline \multirow{2}{*}{ Pengarang } & \multicolumn{4}{|c|}{ Prekwensi Penerbitan } & \multirow{2}{*}{ Total } \\
\cline { 2 - 5 } & 1 & 2 & 3 & 4 & \\
\hline $\begin{array}{l}\text { Jumlah } \\
\text { Pengarang }\end{array}$ & 75 & 7 & 3 & 0 & 85 \\
\hline Duplikasi & 0 & 7 & 6 & 0 & $/$ \\
\hline Total & 75 & 14 & 9 & 0 & 98 \\
\hline $\begin{array}{l}\text { Prosentase } \\
(\%)\end{array}$ & 88,24 & 8,24 & 3,53 & 0 & 100,00 \\
\hline
\end{tabular}

Pada bidang Multi-Disiplin (Studi Islam), dua journal yang mewakili untuk dianalisis adalah journal Studia Islamika dan Journal Indo-Islamika. Analisis Produktifitas Pengarang tersebut dapat disaksikan pada tabel tersebut di atas. Dari paparan data bibliografi dapat diketahui bahwa pada bidang multi disiplin (studi islam) telah terjadi perkembangan yang intens dan dinamis dalam hal kontribusi karya ilmiah pengarang terhadap kajian terkait. Dari analisis bibliografi artikel ilmiah dalam tiga journal tersebut selama periode 5 tahun terakhir sekurangnya tercatat 85 penulis atau peneliti yang berkontribusi dalam publikasi ilmiah bidang Multi-Disiplin Islam atau Islamic Studies. Sekurangnya terdapat 98 judul artikel kajian yang bersifat komprehensif berhasil diakumulasikan dari kedua sumber tersebut.

Dari gambaran peran penulis terlihat bahwa penulisan artikel ilmiah Islam di bidang multi disiplin ini juga terlihat begitu intensif, namun pola produktifitas didominasi oleh penulis satu kali dalam periode tersebut. Sebanyak 75 penulis atau sebesar 88,24 \% adalah mereka yang hanya berkontribusi satu kali dalam periode tersebut. Yang berkontribusi dua kali bahkan jauh lebih kecil, yakni sebesar $8,24 \%$ atau sebanyak 7 orang pada penerbitan dua journal ilmiah tersebut. Mereka itu adalah : Oman Fathurahman, Peter G. Riddell, M. Nur Rianto Al Arif, Jajang A. Rohmana, Dadi Darmadi, Arrazy Hasyim, dan Ali Munhanif. 
Sedangkan pada periode tersebut yang telah berkontribusi tiga kali adalah sebesar 3,53\% atau sebanyak 3 orang pengarang, yakni : Suprapto, Syofyan Hadi, dan Jamaluddin.

\section{D.3. Bagaimana eksistensi journal dalam} area subject kajian ilmiah ke-Islaman

Masing-masing jurnal pada bidangnya dapat diukur kedalaman kajiannya dengan melihat produktifitas publikasi artikel yang bersangkutan secara intensif dan komprehensif. Keluasan dan kedalaman serta relevansinya pada subjek terkait menentukan posisi journal pada bidang tersebut apakah berperan sebagai sumber utama (core journal) ataukah sebagai penunjang pada bidang tersebut. Hal itu tercermin dari keseriusan journal mengelola dan menerbitkan berbagai karya ilmiah yang relevan dan esensial pada bidang terkait.

Indikator untuk mengetahui posisi utama (core journal) dapat dilihat dari beberapa unsur, diantaranya dengan memperhatikan konsentrasi otoritas lembaga penerbitan journal tersebut, bagaimana relevansi juduljudul artikel yang dipublikasi, dan bagaimana fokus-cakupan bahasan artikel-artikel yang tertera di dalam setiap nomor journal. Penerbit journal pada umumnya memberikan informasi tentang deskripsi tujuan dan cakupan bidang kajian dari journal yang bersangkutan. Hal ini juga dapat diidentifikasi dari desripsi tajuk subjek dan kata kunci serta abstraksi pada setiap bibliogafi artikel ilmiah yang dipublikasikan.

Dari data tentang tujuan publikasi serta keluasan dan kedalaman cakupan, terlihat bahwa terdapat journal yang merupakan sumber referensi utama pada suatu bidang atau subjek kajian pada pakultas dan jurusan tertentu. Tetapi juga sebagian lain merupakan kajian multidisiplin atau ekstensi kajian keislaman atau sering disebut studi islam, yang mencakup berbagai aspek kajian yang berkembang dalam ilmu-ilmu ke-Islaman. Journal pada golongan yang kedua ini meskipun bukan sebagai core atau pokok utama referensi pengembangan subjek tertentu tetapi memegang peran penting dan berfungsi sebagai kelanjutan kajian dari berbagai bidang tersebut.

Dari paparan deskripsi tabel di bawah ini dapat dilihat keterkaitan (relevansi) berbagai journal pada bidangnya masingmasing. Pencari informasi perlu mengenali nama-nama journal tersebut dengan baik guna menemukan tema-tema subjek bahasan yang lebih fokus dan relevan, termasuk juga journal-journal lain yang mendukung subjek tersebut. Hal ini juga penting bagi pustakawan yang berkecimpung dalam pengembangan koleksi perpustakaan untuk mengelola journal terkait sesuai dengan bidang kajian baik yang bersifat tercetak ataupun elektronik dengan memastikan ketersediaan dokumen dan menyediakan akses kepada sumber rujukan tersebut dengan mudah. Pustakwan dan pihak-pihak terkait dengan dokumentasi sumber-sumber informasi ilmiah di lingkugan UIN perlu menyadari bersama untuk tetap mengelola sumber-sumber referensi tersebut tetap utuh, lengkap dan dapat diakses dengan mudah baik untuk keperluan rujukan akademik maupun untuk tujuan tinjauan literatur penelitian. Setelah dilakukan kajian otoritas penerbitan dan cakupan bahasan dari journal-journal ke-Islaman yang tersedia di Lingkungan UIN Syarif Hidayatullah Jakarta maka deskripsi journal sesuai dengan pokok kajiannya dapat dilihat pada tabel berikut:

\begin{tabular}{|c|c|c|c|c|c|}
\hline No & $\begin{array}{l}\text { Bidang } \\
\text { Kajian }\end{array}$ & \multicolumn{2}{|c|}{$\begin{array}{l}\text { Journal Pokok } \\
\text { (Core Journal) }\end{array}$} & \multicolumn{2}{|c|}{ Journal pendukung } \\
\hline 1 & $\begin{array}{l}\text { Syari'ah, } \\
\text { Hukum \& } \\
\text { Ekonomi } \\
\text { Islam }\end{array}$ & $\begin{array}{l}\text { a) } \\
\text { b) } \\
\text { c) } \\
\text { d) }\end{array}$ & $\begin{array}{l}\text { Salam } \\
\text { Cita Hukum } \\
\text { lqtishad } \\
\text { Ahkam:Jurnal } \\
\text { Ilmu Syariah }\end{array}$ & $\begin{array}{l}\text { a) } \\
\text { b) } \\
\text { c) } \\
\text { d) } \\
\text { e) } \\
\text { f) }\end{array}$ & $\begin{array}{l}\text { Studia Islamika } \\
\text { : International } \\
\text { Journal } \\
\text { Al-Zahra: Jurnal } \\
\text { Studi Islam } \\
\text { Komprehensif } \\
\text { Journal Indo- } \\
\text { Islamika: } \\
\text { Journal of } \\
\text { Islamic Sciences } \\
\text { Etikonomi } \\
\text { Signifikan } \\
\text { Tauhidinomics }\end{array}$ \\
\hline 2 & Ushuluddin & $\begin{array}{l}\text { a) } \\
\text { b) } \\
\text { c) } \\
\text { d) }\end{array}$ & $\begin{array}{l}\text { Refleksi: Jurnal } \\
\text { Kajian Agama } \\
\text { dan Filsafat } \\
\text { Sabda: Jurnal } \\
\text { Studi IImu- } \\
\text { Ilmu Al-Qur'an } \\
\text { dan Hadis } \\
\text { Journal of } \\
\text { Qur'an and } \\
\text { Hadith Studies } \\
\text { Journal IImu } \\
\text { Ushuluddin }\end{array}$ & $\begin{array}{l}\text { g) } \\
\text { h) } \\
\text { i) }\end{array}$ & $\begin{array}{l}\text { Studia Islamika } \\
\text { : International } \\
\text { Journal } \\
\text { Al-Zahra: Jurnal } \\
\text { Studi Islam } \\
\text { Komprehensif } \\
\text { Journal Indo- } \\
\text { Islamika: } \\
\text { Journal of } \\
\text { Islamic Sciences }\end{array}$ \\
\hline
\end{tabular}




\begin{tabular}{|c|c|c|c|c|c|}
\hline 3 & $\begin{array}{c}\text { Perad- } \\
\text { aban dan } \\
\text { Kebudayaan } \\
\text { Islam }\end{array}$ & $\begin{array}{l}\text { b) } \\
\text { c) }\end{array}$ & $\begin{array}{l}\text { Kultur: The } \\
\text { Indonesian } \\
\text { Journal } \\
\text { For Muslim } \\
\text { Cultures. } \\
\text { al-Turats } \\
\text { : Mimbar } \\
\text { Sejarah, } \\
\text { Sastra, Budaya } \\
\text { Dan Agama, } \\
\text { Narasi: Media } \\
\text { Penelitian } \\
\text { Agama Dan } \\
\text { Budaya, } \\
\text { Manuskripta, } \\
\text { Mimbar: } \\
\text { Jurnal Agama } \\
\text { dan Budaya }\end{array}$ & $\begin{array}{l}\text { a) } \\
\text { b) } \\
\text { c) } \\
\text { d) } \\
\text { e) } \\
\text { f) }\end{array}$ & $\begin{array}{l}\text { Studia Islamika } \\
\text { : International } \\
\text { Journal } \\
\text { Al-Zahra: Jurnal } \\
\text { studi islam } \\
\text { komprehensif } \\
\text { Indo-Islamika: } \\
\text { Journal of } \\
\text { Islamic Sciences } \\
\text { Dialektika } \\
\text { Jauharah } \\
\text { Journal of } \\
\text { Islamic Past and } \\
\text { Present (JIPP) }\end{array}$ \\
\hline 4 & $\begin{array}{l}\text { Pendidikan } \\
\text { Islam. }\end{array}$ & $\begin{array}{l}\text { a) } \\
\text { b) } \\
\text { c) }\end{array}$ & $\begin{array}{l}\text { Tarbiya: } \\
\text { Journal of } \\
\text { Education } \\
\text { in Muslim } \\
\text { Society } \\
\text { Didaktika } \\
\text { Islamika } \\
\text { Arabiyat } \\
\text { : Jurnal } \\
\text { Pendidikan } \\
\text { Bahasa Arab } \\
\text { dan Kebahasa- } \\
\text { araban } \\
\text { Afaq } \\
\text { Arabiyyah: } \\
\text { Jurnal } \\
\text { Pendidikan } \\
\text { Bahasa Arab }\end{array}$ & $\begin{array}{l}\text { a) } \\
\text { b) } \\
\text { c) } \\
\text { d) } \\
\text { e) }\end{array}$ & $\begin{array}{l}\text { Sosio Didaktika: } \\
\text { Social Science } \\
\text { Education } \\
\text { Journal } \\
\text { Edusains } \\
\text { Tazkiya Journal } \\
\text { Of Psychology } \\
\text { Dialektika } \\
\text { Islam Dan } \\
\text { Lingkungan } \\
\text { Hidup: } \\
\text { Medika Islamika }\end{array}$ \\
\hline 5 & $\begin{array}{c}\text { Dakwah dan } \\
\text { Komunikasi } \\
\text { Islam }\end{array}$ & b) & $\begin{array}{l}\text { Dakwah: } \\
\text { Jurnal Kajian } \\
\text { Dakwah dan } \\
\text { Komunikasi } \\
\text { Harkat: } \\
\text { Jurnal Media } \\
\text { Komunikasi } \\
\text { Jender } \\
\text { Journal } \\
\text { Manajemen } \\
\text { Dakwah } \\
\text { Journal } \\
\text { Komunikasi } \\
\text { dan Penyiaran } \\
\text { Islam }\end{array}$ & $\begin{array}{l}\text { a) } \\
\text { b) }\end{array}$ & $\begin{array}{l}\text { Studia Islamika } \\
\text { : International } \\
\text { Journal. } \\
\text { AL-Zahra: } \\
\text { Jurnal } \\
\text { studi islam } \\
\text { komprehensif } \\
\text { Journal Indo- } \\
\text { Islamika: } \\
\text { Journal of } \\
\text { Islamic Sciences }\end{array}$ \\
\hline
\end{tabular}

\section{F. PEMBAHASAN}

Dalam penelitian ini tidak bermaksud untuk melakukan komparasi semua bidang subject ke-Islaman, tetapi tujuan utamanya adalah untuk memberikan gambaran pertumbuhan dan produktifitas karya ilmiah berdasarkan sumber data dan sumber bibliografi yang akumulatif. Data yang sistematis, komprehensif dan akumulatif dibutuhkan untuk memperoleh analisis pertumbuhan dan produktifitas ilmiah pada bidang-bidang terkait secara objectif. Oleh karena itu karena keterbatasan data yang terakumulasi disini data yang diperoleh tidak digunakan untuk melakukan komparasi pertumbuhan antar semua bidang ke-Islaman tersebut. Tetapi dari sumber data yang telah ditetapkan sekitar 500 records dan diperoleh sekitar 498 bibliografi artikel dari beragam journal dalam tiga bidang subjek dapat dijadikan bahan analisis dan disini dipandang cukup memadai sebagai representasi guna melihat pertumbuhan keilmuan dan produktifitas pengarang pada bidang terkait selama periode lima tahun terakhir.

Dari hasil analisis data dapat dikatakan bahwa bidang syari'ah merupakan bidang kajian yang paling berkembang dan produktif dalam melahirkan artikel ilmiah dibandingkan dengan ke dua bidang yang lain. Disini bidang Syari'ah-Hukum nampak paling attractive dalam melibatkan penulis berkontribusi dalam penulisan artikel ilmiah. Namun demikian hal ini tidak dapat dibandingkan lebih dengan bidang lain di luar ketiga subject tersebut karena tidak dapat diperoleh akumulasi data secara konsisten dan representatif dari sumber yang bersangkutan dalam periode yang sama. Misalnya, untuk subjek kebudayaan Islam ditemukan sekitar 54 artikel dari 49 penulis pada dua journal (al Turast dan Manuskripta), lima orang dari jumlah tersebut adalah mereka yang menulis dua kali artikel. Untuk bidang pendidikan Islam (Tarbiyah) ditemukan sekitar 62 artikel dari 56 penulis dengan 3 orang mereka adalah yang mampu menulis dua kali penerbitan artikel dalam kurun waktu tersebut. Karena sumber data bidang-bidang ini tidak diperoleh secara konsisten, data ini tidak dianalisis lebih lanjut.

Uniknya, bila pola produktifitas artikel ilmiah dibandingkan terhadap ketiga bidang yang dianalisis tersebut diatas timbul gambaran yang menunjukkan kemiripan pola dimana katagori penulis yang sangat produktif adalah mereka yang jumlahnya sangat sedikit, sekitar 3,5 \% dan lebih kecil lagi jumlahnya atau sekitar 1,1 \%. Fenomena ini khususnya terlihat pada bidang Ushuluddin. Hal ini sejalan dengan teori Lotka tetapi polanya lebih rendah dari teori tersebut. Secara ringkas gambaran perbandingan pola prosentase dan produktifitas dapat disaksikan pada tabel berikut: 


\begin{tabular}{|l|c|c|c|c|c|}
\hline $\begin{array}{c}\text { Produktifitas } \\
\text { (dalam lima } \\
\text { tahun terakhir) }\end{array}$ & $1 \mathrm{x}$ & $2 \mathrm{x}$ & $3 \mathrm{x}$ & $4 \mathrm{x}$ & Total \\
\hline $\begin{array}{l}\text { Prosentase } \\
\text { (Syari'ah) }\end{array}$ & 79,75 & 16,46 & 3,80 & 0 & 100,00 \\
\hline $\begin{array}{l}\text { Prosentase } \\
\text { (Multi-disiplin) }\end{array}$ & 88,24 & 8,24 & 3,53 & 0 & 100,00 \\
\hline $\begin{array}{l}\text { Prekuensi } \\
\text { (Ushuluddin) }\end{array}$ & 82,76 & 12,64 & 3,45 & 1,15 & 100,00 \\
\hline
\end{tabular}

Dari analisa data tiga bidang tersebut, terdapat hal yang unik yang dapat disaksikan bahwa nilai terendah prosentasi pengarang dengan publikasi satu kali penerbitan dalam durasi lima tahun terakhir justru terjadi pada Syari'ah, padahal bidang ini telah diidentifikasi memiliki paling banyak kontributor artikel ilmiah sekitar $80 \%$ (236 penulis). Namun hal ini masih lebih rendah dari idealitas penulis dengan satu kali publikasi, yang semestinya dibawah 60\%. Sedangkan untuk kategori penulis produktif dalam periode tersebut dengan berkontribusi 3 kali publikasi menunjukkan kesamaan pola dimana dicatat sekitar 3,6 \% penulis termasuk dalam golongan tersebut. hal ini terlihat jelas juga pada syari'ah meskipun jumlah kontributornya terindikasi cukup tinggi. Fenomena ini sejalan dengan teori Lotka tersebut di atas miskipun data menunjukkan tingkat produktifitas yang rendah.

Padabidang Multi-disiplin (IslamicStudies), tingkat produktifitas penulis dengan dua kali penerbitan dalam kurun lima tahun terlihat sangat rerendah, sekitar $8 \%$, dibandingkan dengan kedua bidang yang lain. Sepertinya tingkat prosentase ini tidak dapat dijadikan parameter ukuran produktifitas journal tersebut karena mengingat karakter dari etika penulisan yang ketat, lebih mendalam dan komprehensif. Sehingga rendahnya kuantitas jumlah penulis dalam satu publikasi bukan tolak ukur kemajuan perkembangan atau kemunduran journal tersebut, karena boleh jadi tingkat kesulitan dan kedalaman kajian yang dibahas telah menyebabkan terbatasnya kuantitas penulisan dan prekuensi publikasi.

Beberapa journal kajian yang bersifat universal atau multi-disiplin Islam, seperti Studia Islamika : International Journal, AL-Zahra: Jurnal studi
Islam komprehensif, dan Journal IndoIslamika, merupakan jurnal lintas disiplin yang di dalamnya membahas Islam secara komprehensif. Karena itu sumber ini juga berposisi dan berperan sebagai pendukung beberapa core journal pada subject-subject keIslaman di lingkungan UIN.

\section{G. KESIMPULAN DAN SARAN}

\section{KESIMPULAN}

Setelah menganalisa data yang diperoleh dengan cara mencermati otoritas penerbitan, keluasan dan kedalaman bibliografi artikel dalam beberapa bidang kajian ke-Islaman, maka dapat diketahui dinamika produtivitas karya ilmiah pada bidang kajian yang bersangkutan. Setelah dilakukan analisis produktivitas pengarang dalam berbagai journal ilmiah terkait, yang ditetapkan sebagai sumber dan objek kajian bibliografi pada penelitian ini, maka dapat disimpulkan beberapa hal sebagai berikut:

1. Berdasarkan data dari bibliografi e-journal UIN, bidang kajian ke-Islaman Syari'ah dan Hukum merupakan bidang subjek dengan karya ilmiah yang sangat produktif, progresif dan berkembang pesat dalam kurun waktu lima tahun terakhir dibandingkan dua bidang yang lain : Ushuludin dan Multi-disiplin. Lebih dari 235 peneliti tercatat berkontribusi dalam publikasi ilmiah bidang Syari'ah-Hukum pada periode tersebut dengan akumulasi sejumlah 293 artikel ilmiah yang tertera dalam arsip journal elektronik UIN dari 4 judul journal utama. Jumlah ini belum termasuk beragam artikel yang terbit di journal yang lain. Sementara bidang Ushuluddin mencatat sekitar 107 judul artikel dari 72 penulis yang terekam dalam 3 journal utama dalam kurun waktu yang sama. Dan bidang Multi-disiplin (Studi Islam) mendaftarkan sekitar 98 artikel ilmiah dari 75 ilmuan yang data dokumennya terekam dalam arsip elektronik dari tiga judul journal bidang terkait. Dengan demikian dapat dikatakan bahwa kajian Syariah telah memberikan produktifitas dan publisitas ilmiah ke- 
Islaman yang paling progresif dan paling unggul berdasarkan sumber OJS UIN Syarif Hidayatullah Jakarta pada periode lima tahun terakhir.

2. Dari analisa dua bidang subjek dan satu bidang multi-disiplin dapat disimpulkan bahwa pada prinsipnya pola produktifitas artikel ilmiah dari masing masing bidang memiliki kesamaan model pola dimana prosentase penulis yang paling produktif berjumlah sangat kecil, sedangkan penulis yang (kurang produktif) hanya mempublikasikan satu kali karya ilmiahnya pada periode lima tahun terakhir sangat besar jumlahnya. Jika diklasifikasi maka, sebagian mereka yang tergolong produktif dengan $3 \mathrm{x}$ publikasi dalam lima tahun terakir berjumlah sekitar 3-9 orang penulis untuk masing-masing subjek atau sekitar 3-4 \% dari keseluruhan penulis yang aktif terlibat dalam pengayaan artikel ilmiah pada journal masing-masing, diikuti oleh sebagian mereka pada posisi golongan menengah (cukup produktif) dengan $2 \mathrm{x}$ publikasi dengan jumlah yang lebih besar (8-16\%) padakurun periode tersebut. Tetapi hanya 1 orang yang paling produktif yang mampu menulis 4 kali publikasi ilmiah dalam periode tersebut. Pola publisitas ilmiah ini masih jauh lebih rendah dibandingkan dengan ideal publisitas karya ilmiah sesuai dengan teori Lotka.

3. Deskripsi core journal (journal utama) sesuai bidangnya:

Setelah dilakukan berbagai kajian dan analisis ketersediaan journal ke-Islaman di Lingkungan UIN Syarif Hidayatullah maka dapat diketahui deskripsi journal sesuai dengan pokok wilayah kajiannya dan beberapa journal pendukung untuk subjek kajian terkait dapat dilihat pada tabel matrik pada bagian pembahasan. Journal yang dihasilkan oleh prodi masing-masing merupakan journal utama pada bidangnya, sedangkan journal pendukung dapat diperoleh dari beberapa unit fakultas lain atau dari lembaga studi lanjut seperti sekolah paska sarjana, dan studi lintas disipin seperti kajian bidang psikologi untuk pendidikan sebagai pendukung kajian pendidikan (tarbiyah). Untuk pendukung kajian Tarbiyah juga dapat diperoleh dari journal Islam dan Saints seperti journal Islam dan Lingkungan Hidup dan Medika Islamika, demikian juga publikasi Dirasat Islamiyah untuk mendukung berbagai kajian lain khususnya Syari'ah, Ushuluddin dan Peradaban Islam. Dari segi perkembangan judul journal menurut bidang subjek masing-masing, nampaknya bidang ilmu Peradaban Islam merupakan kajian yang memiliki dukungan pertumbuhan journal yang sangat komprehensif, demikian juga bidang Tarbiyah.

\section{SARAN - SARAN}

Berdasarkan pengalaman penelitian dan kendala yang dialami dalam proses penelitian dan ditemukannya kelemahan-kelamahan dalam sistem database dan sistem informasi perpustakaan maka dapat disarankan hal-hal sebagai berikut:

1. Sistem perpusakaan dan informasi UIN Jakarta hendaknya melakukan perbaikan sistem katalog dan indeksing sumbersumber ke-Islaman sehingga data bibligrafi dan aktual teks karya ilmiah dapat tersedia secara lengkap dan sistematis dalam arsip database baik dalam jaringan off-line, online elektronik, maupun maunal.

2. Lembaga perpusakaan terkait dilingkungan UIN Jakarta khususnya perpustaaan pusat hendaknya selalu melakukan perbaikan sistem organisasi dan penataan koleksi journal tercetak agar susunan koleksi selalu tetap terjaga sistem temu kembali yang sistematis, up to date dan mudah diakses oleh semua user.

3. Untuk para peneliti lain pada bidang sama dalam kajian biliometrika karya ke-Islaman agar dapat melanjutkan dengan kajian dan penelitian yang lebih luas atau mendalam, untuk mendapatkan gambaran hasil yang lebih komprehensif lagi

4. Diketahuibanyaksekalipenulishanyasekali 
publikasi dalam kurun waktu empat sampai dengan lima tahun, lembaga penelitian dan lembaga lain terkait hendaknya selalu mendorong sivitas akademika untuk meningkatkan produktifitas dan publikasi karya ilmiah di bidangnya masing-masing. Hal ini khususnya pada homebase bidang kajian yang partisipasi dan produktifitas ilmiahnya rendah, yang mayoritas tenaga edukatornya bekontribusi selama $4 \quad-5$ tahun terakhir hanya satu kali penerbitan.

5. Para prodi dan lembaga terkait berkemauan untuk menerbitkan journal baru atau peningkatan publikasi ilmiah kontemporer sesuai dengan problematika, kajian dan fenomena masyarakat modern. Per prodi 1 journal untuk mendukung dinamika pertumbuhan ilmu dan peningkatan kualitas, serta penguatan bidang kajian keIslaman.

6. Untuk lembaga-lembaga kajian di lingkungan UIN agar dapat menyediakan SDM khusus untuk pengelolaan journal ilmiah, agar journal yang sudah diciptakan dapat terus terbit secara periodik, kontinyu dan konsisten baik secara manual maupun elektronik.

\section{DAFTAR PUSTAKA}

Andrea Diem and Stefan C. Wolter. The Use of Bibliometrics to Measure Research Performance in Education Sciences. Research in Higher Education. Vol. 54, No. 1 (February 2013) (pp. 86-114).

Arsenova, Iskra. New application of bibliometics. www.sciencedirect.com

Charless H. Busha dan Stephen P. Harter. Research Methods in Librarianship: Techniques and Intepretation. New York: Academic press, 1980.

Bopp, Richard E. Reference and Information Services: an Introduction, 3ed. Colorado: Libraries unlimited. 2001

Christian Smith. http://www.nada.kth.se/ ccs/ Publications/bibliometry.pdf

E. Beck, Susan. And Kate Manual. Practical Research Methods for Librarians and Information Professionals - Blibliometrics. London: Neal-Schuman Publishers, Inc. 2008.

Georges Toops. The Problem of Bibliometry: http://www.kaowarsom.be/documents/
evaluation/Stoops_Problem_bibliometry_Reflections_Use_Evaluation_Research_ South.pdf

Jean-Pierre V. M. Hŭrubel. Historical Bibliometrics: Its Purpose and Significance to the History of Disciplines. Libraries \& Culture,Vol. 34, No. 4 (Fall, 1999), pp. 380388.http://www.jstor.org/stable/25548766

J. J. Hubert. Bibliometric Models for Journal Productivity. Social Indicators Research, Vol. 4, No. 4 (Oct., 1977), pp. 441-473. http:// www.jstor.org/stable/27521841

Neuman, W. Lawrence. Social research method: qualitatif and quantitative approaches. New York: Pearson Education, 2003.

Pendit, Putu Laxman (2003), Penelitian Ilmu Perpustakaan dan Informasi: Sebuah Pengantar Diskusi Epistemologi dan Metodologi. Jakarta: JIP-FSUI.

Richard E. Rubin. Foundations of Library and Information science. London: Neal Schuman Publishers, inc.

Simon Michael Braune. Islam as Practiced by the Kazak: A Bibliography for Scholars. MELA Notes, Middle East Librarians Association No. 78 (2005), pp. 1-17. http://www. jstor.org/stable/20839899 